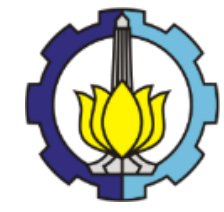

$8^{\text {th }}$ International Conference on

Architecture Research and Design $(\mathrm{AR}+\mathrm{DC})$

November 1-2, 2016

\title{
Appearance of unplanned settlement as a reality in Medan City and surrounding area
}

\author{
Beny OY Marpaung ${ }^{\mathrm{a}^{*}}$ \\ ${ }^{a}$ Department of Architecture - University of Sumatera Utara, Jalan DR. Mansyur No.151, 20155, Indonesia \\ *Corresponding author. Tel.: +62811617121; fax: +62618219525. \\ E-mail address: beny.marpaung@usu.ac.id
}

\begin{abstract}
Many unplanned settlements have appeared in Medan City and its surrounding areas. In general, people living in unplanned settlements have come from middle to lower class communities. The process and the components of unplanned residential areas arrangements are indeed related to social situation of their inhabitants. Social circumstances of unplanned settlements in Medan City and its surrounding areas offer a challenge to research about various forms of unplanned settlements; the pattern of buildings position and roads; and the people's mindset in building the physical environment. The settlements are formed based on the inhabitants' mentation which has its own characteristics. The study observes the possibility of spatial phenomena in a residential area that is formed unplanned. The location of this study is on unplanned settlements inside and outside Medan City. The research area is a settlement in Kelurahan Polonia and Silalas at Medan City and Besilam Babussalam Langkat which is located outside Medan City. This study uses qualitative methods to analyze and obtain discovery. Variables and data are determined based on the research of the theoretical basis. The conclusion from this study is the form of unplanned residential district tends to born from its inhabitants' idea and the forming process of unplanned settlements really affects the development of the settlements itself.
\end{abstract}

Keywords: form; settlements; unplanned; community

\section{Introduction}

Settlements are created because of the residence forming process. Residence forming is a functional vessel which is based on the patterns of human activity and the effect of setting (layout). The pattern may be physical and nonphysical (social and cultural), which directly affects the activity pattern and placement process. This study observes the existence of a phenomenon of the settlements that are formed unplanned. Researchers make an observation in Kelurahan Polonia and Silalas in Medan City and Besilam Babussalam Langkat which is outside Medan City. Communities occupy the land that was formerly an arable land in Medan City and in its hinterland. The residential community can come from certain ethnic and even some other ethnics. The arable land grows into residential areas and the settlements may be in the possession of a particular ethnic community. In the past, the immigrant community arrived at Medan city and its hinterland through a transmigration program, by following parents or because there is a desire to seek a better life than the one they have in their homelands. The residents' mentations give a lot of impact on the occurrence of some forms of residential areas. Forms of settlements tend to be cluster in a few zones and linear in the area oriented to the street. The settlements that are created based on the inhabitants' mentation have their own characteristics. The researcher studies the possibility of spatial phenomena in a residential area that are formed unplanned. This knowledge becomes the basis for developing a scientific research about physical manifestations of 
unplanned settlements. Physical manifestations of unplanned settlements are discovered by researchers based on the analysis of the influence of social reality towards occupants' living space.

\section{Research Theories and Methods}

In general, the development of unplanned settlements is based on the occupants' activities which they carry out based on their wills. (Kostof, 1991). Society does the activity by following the norms and their own understanding as well as the knowledge they possess and these affect their ability to create forms and spaces of the area they occupy. The rationale for the community in establishing a settlement results in the formation of characteristic physical manifestations. Society's thought is a comprehensive action and a necessary element in creating a regional identity (Kabir \& Parolin, 2012). Society's thought will affect the blocks arrangements and the street pattern in a region and create a model that is familiar to the users. The settlement formation process will be able to be understood and discovered based on society's thoughts (Sarkar, 2010).

Factors that influenced the shape of unplanned settlements are (Katsamudanga, 2007; Květina \& Končelová, 2013; Mckay, 1968; Sarkar, 2010; SCOTT, 1996) economic factors, topography, climate conditions, soil conditions, defense factors, social factors, and urbanization. In choosing a place to stay on a settlement, the existence of economic activities in the vicinity such as shopping centers, industrial, mining, agriculture, plantation and fisheries will be taken into consideration. The topography form such as mountains, valleys, plateaus, plains and coastal areas affects the community in placing their house. Likewise, the climate conditions in each region. Society must adapt to survive thus changing their thoughts in creating a settlement form. Besides, the state of arable land is also a consideration for people in deciding where to stay. Settlement form can adjust to agriculture and plantation development area, results in the settlement patterns that occured tend to be organic. Defense factors also affect society in shaping the settlement. Settlement forms are affected by the need for defense against external attacks. Furthermore, according to (Rapoport, 2000), initially, the residential areas shaped in a settlement were affected by socio-cultural factors. These factors were ideas, ways of life, the views and characters of its people. The availability of the relation between social conditions and the formation of settlements becomes a natural adaptation process for the society. The adjustment process is believed to be the source of strength for their character in forming a settlement. Unplanned settlements can occur as a result of urbanization factor. Immigrants chose to settle illegally in the area that is not designated for them.

Unplanned settlement forms can vary. Categories of unplanned settlements form (Fernandez-rosa, 2011) are settlement with an organized grid pattern, settlement with irregular grid pattern, settlement pattern that is adapted from the topography of the land, settlement with corridor centered pattern, settlement with radial pattern, settlement with stage circulation pattern, compact development (settlement patterns with a dense central region), scattered development (settlement patterns which are randomly distributed), linear strip development (linear settlement patterns), polynucleated development (scattered settlement pattern that has multiple central areas at random), and leapfrogging development (dispersed settlement pattern but with denser central area).

In the method of determining the location of the study, some observations which are carried out are the observations upon (1) people occupy land illegally; (2) the settlement grew or formed based on the occupants' thought; (3) government and architects do not intervene in the process of residential areas formation. Research variables are determined based on the theoretical basis in this study and linking it to research problems. Data collection methods refer to the variable about society's thought and settlements forms. Data are collected by distributing questionnaires and conducting interviews. Results of the questionnaire are processed using quantitative method and qualitatively analyzed by connecting them to the theory of perception and settlement forms. The interview results are interpreted by connecting them to the observations of the physical state of the settlements and the theory concerning society's thought and residential area shape. 


\section{Results and discussions}

This study observes Silalas settlement and settlement at Kelurahan Polonia. These two settlements are located in Medan City. In addition, another observation is made on settlements in Besilam Babussalam langkat which is located outside Medan City.

\subsection{Silalas Settlement}

Silalas settlement is located at the southern part of the subdistrict of West Medan (Fig.1), Medan City Indonesia. Silalas settlement consists of twelve (12) administrative zone with a population density of 4,641 inhabitants per kilometer. At first, this settlement was dominated by Malays. Malays communities built settlements on the banks of Deli River, therefore, the riverside area is one of the Malays criteria in selecting land settlements. According to (Rapoport, 2000), settlements will form by making the residences into functional area from the cultural process in the community activities. For the Malays, river is the source of life. Besides, river is a means of transportation and water resources for fulfilling daily needs. Deli River at that time was a major transportation route which disembogued into the Strait of Malacca. River cannot be separated from cultural activities of Malays. Currently, the residents of this settlement consist of several different ethnics: Mandailings, Malays, Chinese, Indians, and Bataknese. Silalas settlements grew unplanned based on tradition trusted by the Malays and Mandailing ethnics. Malay Ethnic built Silalas settlements of Deli Riverbanks then grew steadily with particular morphology. After the entry of Mandailaing ethnic, settlement morphology developed toward the land but was still oriented toward the river since the river had a significant role at that time. Settlement patterns formed were irregular grid (Table 1). According to the theory from (Fernandez-rosa, 2011) regarding the unplanned settlements with grid form, physical patterns that are in such settlements usually occur because of ground conditions that tend to create flat topography.

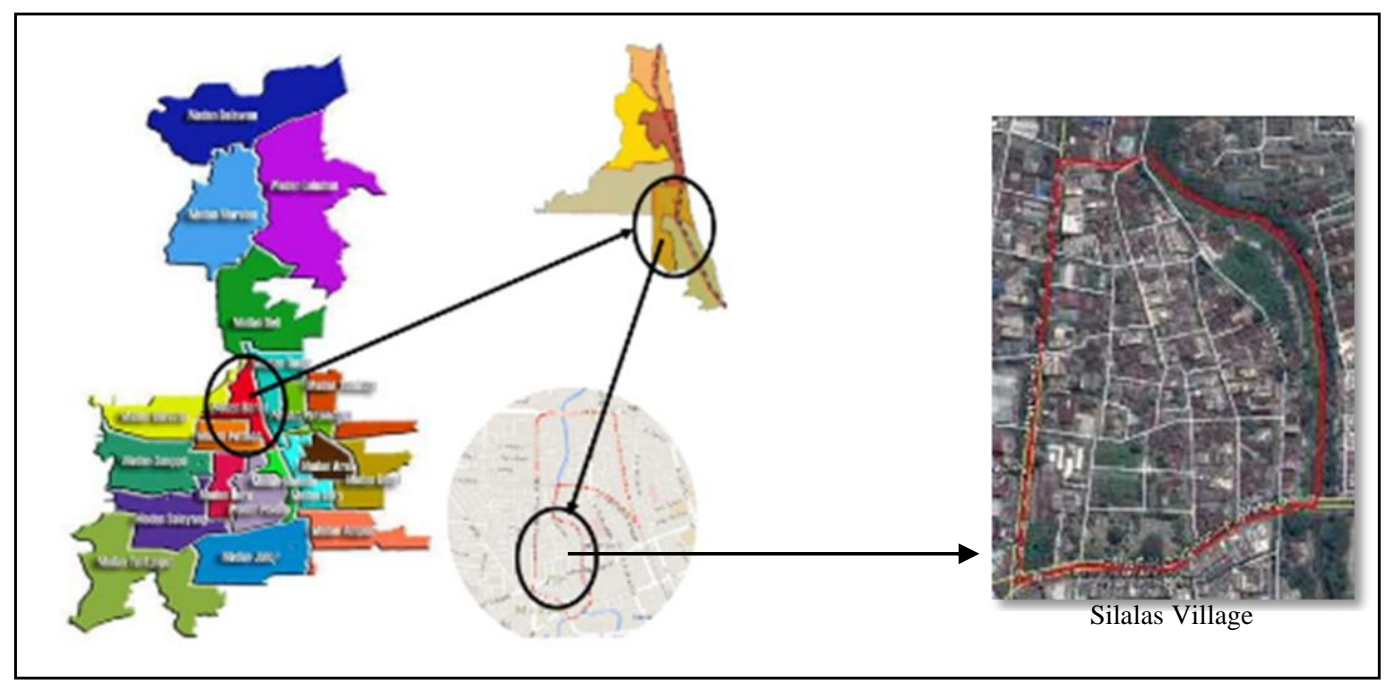

Fig. 1. The Location of Silalas Settlement in Medan City. 
Table 1. Reality of Silalas Settlement.

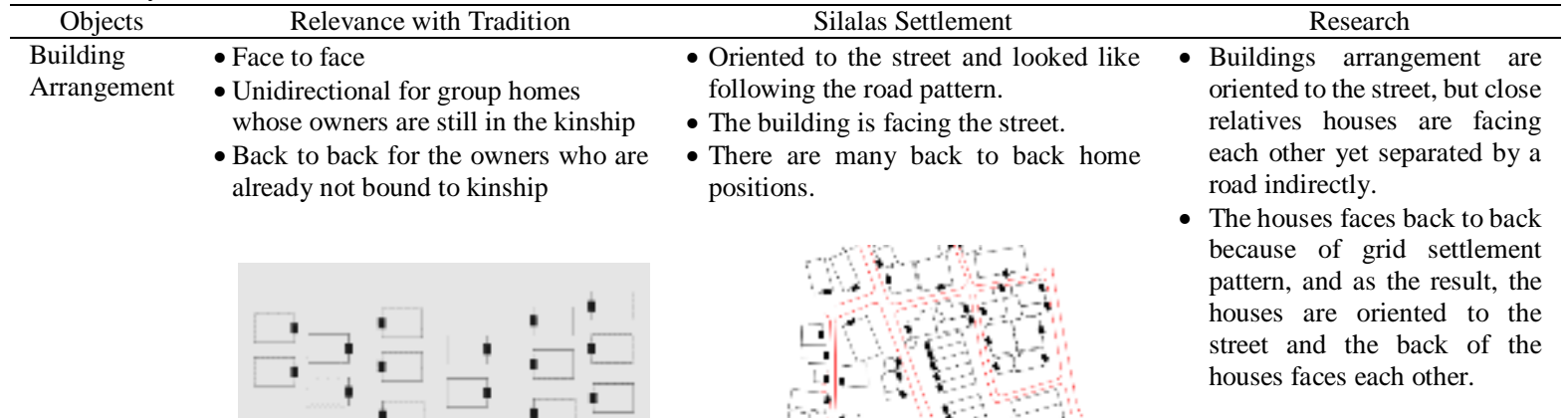

Building

Street

Roads are oriented to the place where the sources of life and daily activities are.

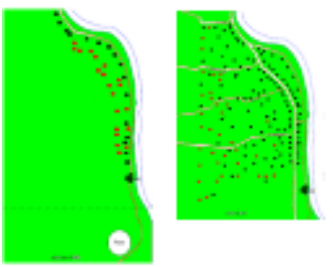

Open Space

- Its exterior place was formerly the resident's garden.

- There are a public open space called alaman bolak and a shared open space among neighbors called alaman and pamispisan.

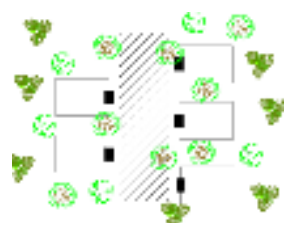

- Roads in Silalas Settlement have been large in number and crisscrossed.

- Paths can access all points in settlements.

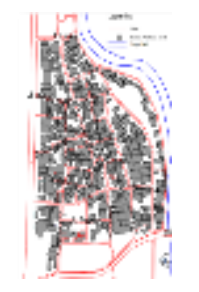

- There are no more plantations.

- There is no Alaman Bolak, open space and guarding office.

- There is no shared open space anymore and houses for the descendants as well as roads are built on it.

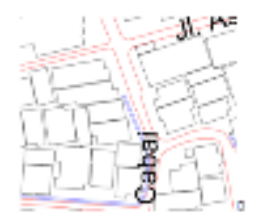

- The change in society's needs makes the society creates a grid-shaped road access so that one point inside Silalas Settlement can be reached from many alternatives roads.

- In the settlements, there are no traditional buildings that nothing becomes the center of road orientation in Silalas Village.

- Silalas Village community continues to grow, and the need for residential land has also increased and changes the land function.

- The previous forest land use changed into plantations then turned into a shared open space and now becomes residential area

- The needs of open spaces are fulfilled by making certain spots become a place to do activity together such as guard post, food stalls, and roads at intersection. 


\subsection{Settlement in Kelurahan Polonia Medan}

Kelurahan Polonia has a total area of about $1.77 \mathrm{~km}^{2}$ and approximately $19.84 \%$ of the total area of Medan Polonia District. There are 13 neighborhoods in the Kelurahan. Geographically, the Kelurahan is located in the southern part of Medan City. Its location is in the middle (central) district of Medan Polonia (Fig. 2). Community's thought has an important influence in shaping the physical environment of the settlement in Kelurahan Polonia (Table 2). Researchers found the six form of residential areas, namely (1) organic form, proved with the shape, the structure of residential area irregular form as well as outdoor space irregular form as a result of the residential area irregular form. The residential area is formed naturally without any planners or decision-makers. (2) Linear form, proved with the residential community area that formed along the streets in this Kelurahan Polonia. In other words, position of residential area follows the shape of the road because the road serves as means of transportation. (3) Cluster form, proved with the residential area arranged in a cluster. In general, the residential area is a residential area formed based on clans or family names. (4) Central corridor form, proved with the road as primary access for activities and also the streets and alleys which became a branch of the main hall. The road branches gather and become a single path towards the central access. (5) Grid irregular form, proved with the streets of Kelurahan Polonia form boxes with irregular intervals. The pattern splits the surface in this district into clear units. (6) Leapfrogging development form (scattered pattern with a denser populated area exists in it), proved with the overall spreading of residential area, yet, there is a denser occupancy area. The amount of population in Kelurahan Polonia significantly affect this pattern.

In studying the settlement form in Kelurahan Polonia in Medan City, the approachment used is the figure-ground method. Based on this method, the researcher blackens the area covered by building mass and light-colors the parts that do not covered by the building mass. Figure-ground method is executed to ease researchers in identifying the settlement form at Kelurahan Polonia on macro scale. Based on this method, researchers identify that the road growth tends to start in the region oriented to the river. That situation is a result of the river is being used as a source of life for the community. The impact is the river bank area becomes more densely populated residential area. That fact is corresponding to (Joko, 2002) theory which explained that in general, river is used as source of life in fulfilling daily needs, as a result, settlements tend to grow on riverbank area.

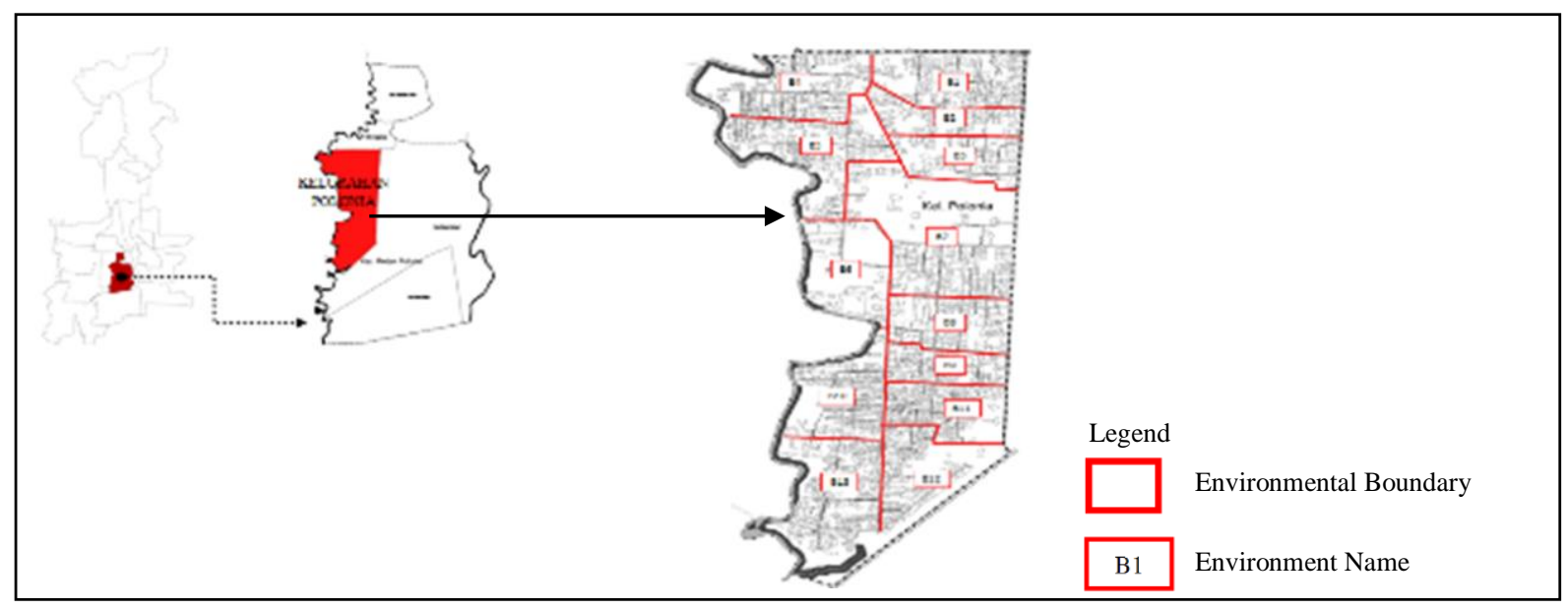

Fig. 2. Settlement in Kelurahan Medan Polonia.

In fact, the public perception of Polonia Settlement has a vital influence in shaping the manifestation of physical environment. The mass buildings in residential areas become irregular. Society formed a mass arrangement of buildings on arable land according to their knowledge. Government and architects also did not involve themselves in the shaping process. Later, residents also did not think about the impact on such irregular residential areas. Besides, 
the composition of existing roads in these settlements is also the result of cooperation between communities. There are also communities that exist which provide land for the sake of common interest.

The residential area pattern and roads arrangement in every neighborhood in Polonia Settlement is an organic pattern. This pattern may last through a long and natural process. The presence of open space also forms an irregular pattern. Physical manifestations of existing roads have straight line geometric forms thus creating an irregular grid pattern.

Table 2. Unplanned Settlement in Kelurahan Medan Polonia.

\begin{tabular}{|c|c|c|}
\hline Shape & Finding & Discussion \\
\hline $\begin{array}{l}\text { Legend } \\
\square \text { : Building Mass } \\
\text { : Babura River }\end{array}$ & $\begin{array}{l}\text { - The shape of building masses are } \\
\text { asymmetric square. The position between } \\
\text { one building mass and another building } \\
\text { mass tends to be irregular } \\
\text { - As an effect of irregular configuration of } \\
\text { the building masses, the road and outdoor } \\
\text { spaces which are formed also have } \\
\text { irregular dimensions. } \\
\text { - Irregular exterior space is formed because } \\
\text { of symbiotic relationship between the } \\
\text { physical and social environment. }\end{array}$ & $\begin{array}{l}\text { - The fact corresponds with the Kostof } \\
\text { (1991: 43)'s theory, that unplanned } \\
\text { settlement has its own uniqueness such as } \\
\text { irregular form, winding roads or } \\
\text { circulation that produce corridors around } \\
\text { the residence. Either the road or corridor } \\
\text { is used as irregular public spaces. } \\
\text { The differences between high density } \\
\text { area and low density area are the cause of } \\
\text { uncontrolable growth in a settlement. } \\
\text { That is the result of lacking the right } \\
\text { decision maker in building the settlement } \\
\text { (Kabir and Parolin, 2011). }\end{array}$ \\
\hline
\end{tabular}

- There are several residential areas that formed along the streets

- Residential areas that are arranged lengthwise grow naturally and create a straight line pattern.

- People living along the roads use their houses for business such as trading to increase their economy

Central Corridor

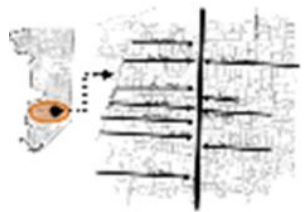

Legend

: The road which becomes the main corridor

$\longrightarrow$ : The road which becomes a branch of the main corridor

Leapfrogging Development (The pattern of spread but some areas are more densely)

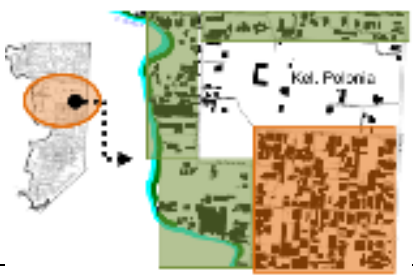

- In accordance with time, population tends to grow. This growth will affect the shape of the residential area.

- The residential areas at Kelurahan Polonia scattered unevenly all over the area. As a result, a higher density and lower density residential areas are formed.
- The population growth that occurs in a settlement will affect the shape of the residential area itself (Scott, 1996: 416).

- The existence of the difference between high density area and low density area results in uncontrolable growth. That is the the results of lacking the right decision maker in building the settlement (Kabir and Parolin, 2011).

- The population growth that occurs in a settlement will affect the shape of the residential area itself (Scott, 1996 : 416).

- The differences between high density area and lowdensity area are the cause of uncontrolable growth in a settlement. That is the result of the lacking of the right decision maker in building the settlement (Kabir and Parolin, 2011). 


Shape
Legend
Babura River
The green area on the edge of the river
The high density residential area
$\square$ The lower density residential area

Irregular Grid

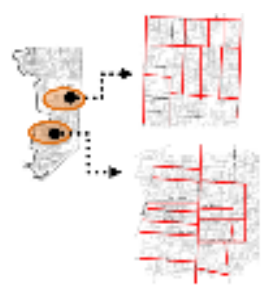

- Some streets form a grid pattern irregular.

- The grid pattern shape is integrated with the building mass locations which are located as how the owners wanted.

- The square grid could divide the surface into countable units and give out certain texture.
- The growth of a settlement related to the occupants' activities in it which those activities is done as the owners' wish (Kostof, 1991:48).

\subsection{Malays Settlement in Hamlet 2 Besilam Babussalam Langkat}

Besilam Babussalam (Hamlet 2) settlement is a hamlet located at Padang Tualang Subdistrict (Fig. 3). Padang Tualang Subdistrict is a region in Langkat which position is outside Medan City. Settlement in Besilam Babussalam was formed without the government's role in it (Table 3). According to (Kostof, 1991), the settlement which occurred unplanned developed as the time flowed and the society's activities in it eventually formed the settlement. The family relationship also plays a significant role in the settlement development. Many communities around the settlement come from the same lineage and spread inside the settlement. (Kostof, 1991) revealed that at first the people gather together in a society which is based on kinship, social status or same work field.

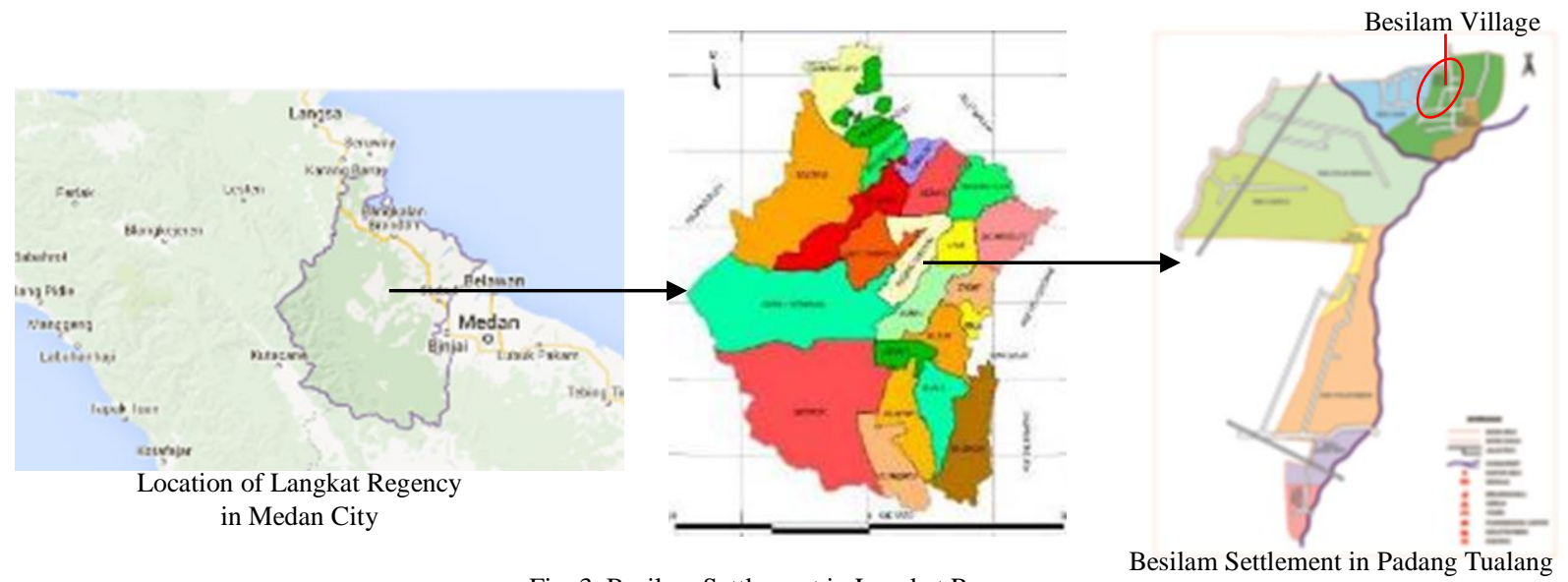

Fig. 3. Besilam Settlement in Langkat Regency. 
In the process of a settlement development, the roads patterns around the settlement consist of a main road and footpath. The main road is the road that divides the settlements. The footpath is a connecting road between each building. Based on interviews, some facts obtained about road pattern in this habitation are that community patterns the road based on the occupants' movement in the settlements. Through field observations, the patterns form tend to be linear path. According to (Fernandez-rosa, 2011), patterns of unplanned settlements usually have flat ground conditions or topography. The conclusion about this form is that it will be easier to be developed because of the ease in additional infrastructure.

Table 3. Besilam Settlement in Langkat Regency

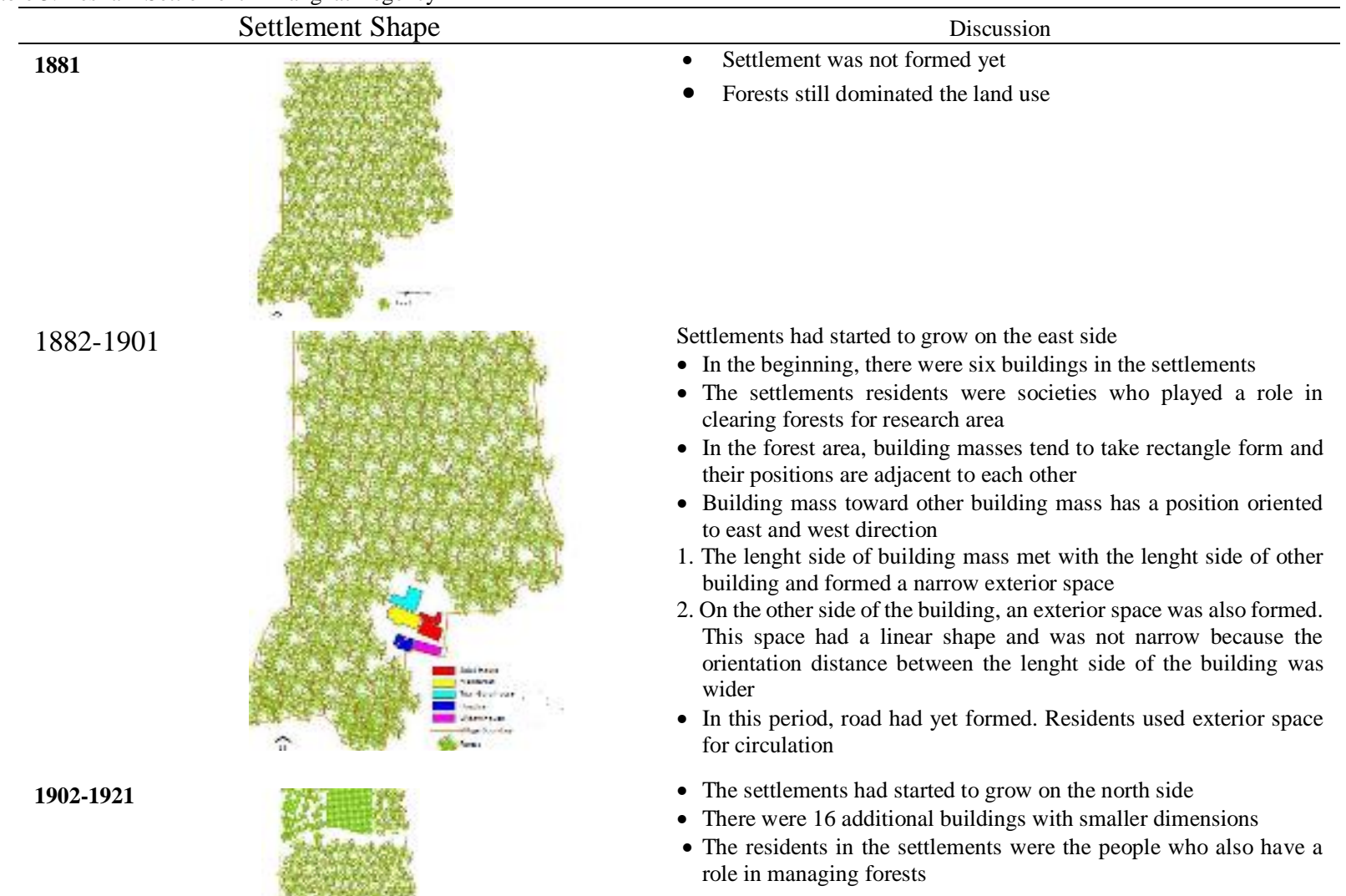

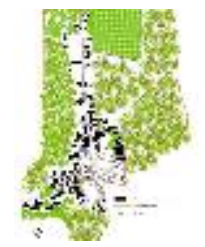

- The settlements had started to grow on the south, southwest, west and north side

- The increasing number of houses became more significant 


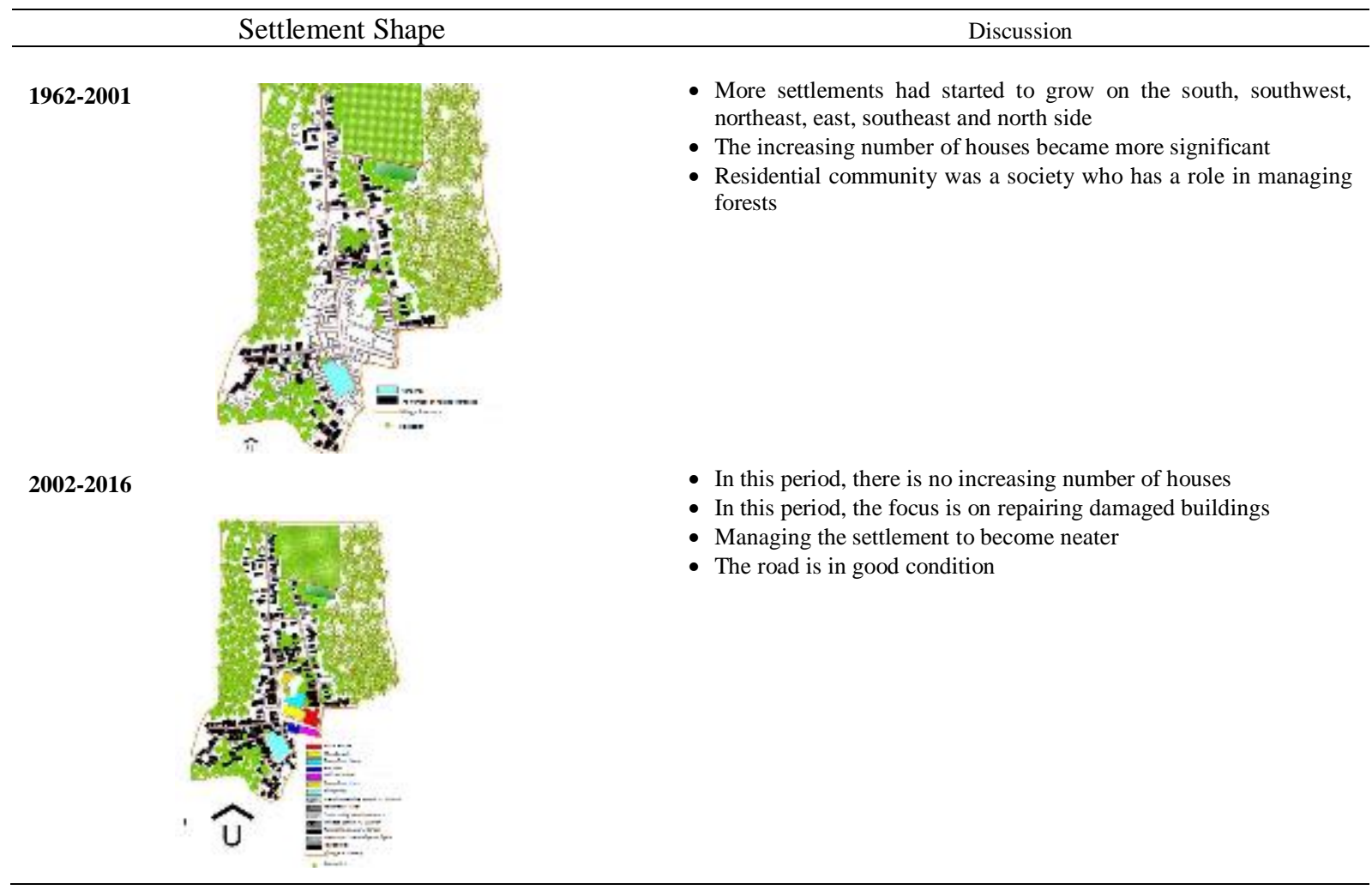

\section{Conclusion}

A settlement was formed through a long process. Settlement history is imperative to be observed and understood as knowledge development about settlement forms. In particular periods, ethnicity has a significant role in changing the settlement form. Thus, the theories stated will facilitate the explanations of a statement or an idea. Researchers can have an idea based on the logic about relationship existence. The relationship is about the influence of human social and cultural characteristics at the countryside towards the formation of physical manifestation of a place in a new area they occupy. In fact, people living in unplanned settlements are residents who originally came from a village. Basically, rural communities have norms that affect their ability to create the concept of form, space and the sociocultural concept itself. That condition can happen in the community when they still lived in the village. The norms they believe give the ability to create their home surrounded by public roads. Naturally, the residence location resulted in a close and advantageous space for the inhabitants of the village. They tried to create a space that can accommodate the actual natural life. That situation could occur based on their socio-cultural reality in a particular period. As a result, the formed space succeeded in becoming the inhabitants community space.

This study of settlement forms can become an input for Medan City Government in planning the structure and morphology as well as policies on curbing residential area in Medan and its surrounding areas. The study finds that residential areas have irregular shapes. The forms of one residential area toward other residential areas are also irregular. Exterior spaces formed have irregular dimensions. The roads shapes are geometric straight line which creates an irregular grid pattern. People's thoughts have significant influence in shaping the physical environment of settlements. Communities also give some of their lands as roads for the sake of common interest. Society has a significant participation in building the environment in the interests of society's comfort. The desire to participate 
affect public personality for their needs. Society's social and cultural values influence the individual character in an area and can determine the orientation of life. Social and cultural values of a rural community usually have stability and resilience in overcoming changes in sociocultural values. That condition is related to the mindset that radiates through the society's knowledge. Those mentalities show how they solve problems by understanding the similar problems that have arisen in the past. Then people started to think about the actions necessary at this period. Furthermore, the public thinks about the implementation of activities in the future after considering and studying the events of the past and the present. All those thinking process are based on needs, and give rise to an idea which affects the activity (traditional society's social conditions) and the characteristics of the physical manifestations.

\section{Acknowledgment}

This paper is the publication of research conducted by the author together with students who participate in The Study of Planning Environment Establishment course in Department of Architecture at the University of Sumatera Utara. The author would like to thank the students for their excellent cooperation as research fellows. This study is also one of the products granted to compete funded by RISTEKDIKTI.

\section{References}

Fernandez-rosa, F. (2011). Physical and Spatial Characteristics of Slum Territories Vulnerable to Natural Disasters. Les Cahiers de l'Afrique de l'Est, 44, p.5-22.

Joko, T. (2002). Arah Perkembangan, Bentuk dan Struktur Fisik Keruangan Kota Pangkalan Bun - Kumai Kabupaten Kotawaringin Barat Propinsi Kalimantan Tengah. Universitas Diponegoro.

Kabir, A., \& Parolin, B. (2012). PLANNING AND DEVELOPMENT OF DHAKA - A STORY OF 400 YEARS. In 15th International Planning History Society Conference (pp. 1-20). Sao Paulo.

Katsamudanga, S. (2007). Environment and Culture: A case Study of Prehistoric Settlement Patterns in the Eastern Highlands of Zimbabwe. University of Zimbabwe.

Kostof, S. (1991). The city shaped: urban patterns and meanings through history. Little, Brown and Company.

Květina, P., \& Končelová, M. (2013). Neolithic LBK Intrasite Settlement Patterns: A Case Study from Bylany (Czech Republic). Journal of Archaeology, 2013, 1-7. https://doi.org/10.1155/2013/581607

Mckay, J. (1968). A REVIEW OF RURAL SETTLEMENT STUDIES FOR TANZANIA. East African Geographical Review, $1968(6), 37-49$.

Rapoport, A. (2000). Theory, Culture and Housing. Housing, Theory and Society, 17(4), 145-165. https://doi.org/10.1080/140360900300108573

Sarkar, A. (2010). Analysis of Human Settlement Patterns Using RS and GIS in the Plains of West Bengal. The On-Line Indian Journal of Spatial Science, 1(1), 1.1-1.16.

SCOTT, M. J. (1996). Human Settlements in a Changing Climate: Impacts and Adaptation. In R. T. Watson, M. C. Zinyowera, \& R. H. Moss (Eds.), Human Settlements in a Changing Climate: Impacts and Adaptation (pp. 399-426). Cambridge: Cambridge University Press. 